Discussion Paper No. 05-55

\title{
Benefits of Control, Capital Structure and Company Growth
}

Elisabeth Müller

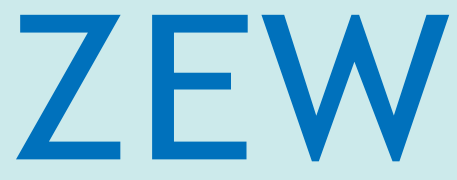

Zentrum für Europäische Wirtschaftsforschung $\mathrm{GmbH}$

Centre for European

Economic Research 
Discussion Paper No. 05-55

\title{
Benefits of Control, Capital Structure and Company Growth
}

\author{
Elisabeth Müller
}

Download this ZEW Discussion Paper from our ftp server:

\section{ftp://ftp.zew.de/pub/zew-docs/dp/dp0555.pdf}

Die Discussion Papers dienen einer möglichst schnellen Verbreitung von neueren Forschungsarbeiten des ZEW. Die Beiträge liegen in alleiniger Verantwortung der Autoren und stellen nicht notwendigerweise die Meinung des ZEW dar.

Discussion Papers are intended to make results of ZEW research promptly available to other economists in order to encourage discussion and suggestions for revisions. The authors are solely responsible for the contents which do not necessarily represent the opinion of the ZEW. 


\section{Non-technical Summary}

Owners of private companies often attribute a high valuation to the control they can exert over their companies. In addition to profits, this control is part of the ownership benefits they enjoy. This paper analyses how attaching a relatively high importance to control influences the development of companies. Specifically, we look at the use of different financing instruments and the growth of companies.

In order to investigate the consequences of the benefits of control, it is important to be able to quantify them. For instance, owners can exert control by voting at their company's annual shareholder meetings. We approximate the extent of control by the probability of the largest owner winning a vote. We then calculate the probability of winning following a hypothetical equity increase. Potential loss of control is measured by the difference of the probability of winning a vote before and after this hypothetical increase. If the potential loss of control is higher, the owner would lose more private benefits in an equity expansion. To study the influence of control, information on almost 9,000 private UK companies with limited liability is used.

The analysis has three main results. First, we find a negative relationship between potential loss of control and the size of equity increases. Owners who lose more control for a given equity increase face a cost component in addition to the required return on the new equity - the cost of losing influence. This makes equity increases less attractive.

Second, we find that potential loss of control is positively related to the leverage of companies. Companies in which existing owners would lose more control in an expansion rely more extensively on bank financing and therefore have higher leverage than otherwise comparable companies. Owners are prepared to pay higher interest rates for additional loans in order to maintain control.

Third, the relationship between potential loss of control and company growth is negative. This is a consequence of the first two results. Some growth opportunities become unprofitable, if they are financed with debt in a situation where debt levels are already high. Even if the returns of the growth opportunity exceed the cost of equity capital, equity finance may not be used, because a control premium is demanded. As a result, fewer growth opportunities will be realised and company growth will be smaller. 


\title{
Benefits of Control, Capital Structure and Company Growth
}

\author{
Elisabeth MuelleR*
}

June 9, 2005

\begin{abstract}
This paper studies the influence of the private benefits of control on the capital structure and the growth of private companies. It is argued that companies in which existing owners would lose more control if they expanded, have smaller equity increases, are more highly levered and grow more slowly. The dataset covers 8,964 private UK companies with limited liability for up to 5 years. Potential loss of control is measured as the difference in the probability of winning a vote for the largest owner before and after a hypothetical equity increase. Consistent with the private benefits of control, the results show that companies with a high potential loss of control do indeed have smaller equity increases, use more debt and grow more slowly.
\end{abstract}

JEL classification: G32, G34

Keywords: benefits of control, capital structure, company growth, small and medium-sized enterprises, entrepreneurship

*Centre for European Economic Research (ZEW), Department of Industrial Economics and International Management, L7,1, 68161 Mannheim, Germany, e-mail: Mueller@zew.de

Acknowledgements: I would like to thank Ron Anderson, Christian Laux and Steve Nickell for helpful discussions and seminar participants at the London School of Economics, the University of Manchester, the University of Mannheim and the Centre for European Economic Research (ZEW) for useful comments. All remaining errors are my own. 


\section{Introduction}

In many industrialised countries, governments are concerned that small companies find it difficult to obtain enough finance to realise their growth potential (e.g., Cressy (2002); Wren and Storey (2002)). However, owners would sometimes not accept additional finance, even if it were available, because they want to remain in control of their companies. They want to remain in control because they obtain private benefits over and above the financial return on their investment. In order to stay in control they need to forego some growth opportunities, if the opportunities are too extensive to be realised with debt finance alone. This means that companies do not reach their growth potential and employ fewer people than would otherwise be the case 1

Surveys document the importance that owners give to keeping control of their companies (e.g., Cressy and Olofsson (1997); Poutziouris et al. (1998)). However, so far, it is unclear what effect this may have on company characteristics such as the use of different financing instruments and the growth of companies. This paper tries to answer this question.

A possible method of investigating the consequences of the private benefits of control is first to calculate how much control the largest owner would lose in a hypothetical equity increase. This potential loss of control can then be related to company characteristics of interest. The extent of control is approximated by the probability that the largest owner will win a vote. Potential loss of control is calculated as the difference in the probability of winning a vote before and after a hypothetical equity increase.

This paper tests three hypotheses. The first two hypotheses are related in that they are concerned with the use of financing instruments; the last hypothesis is related to company growth. First, we expect a negative relationship between potential loss of control and the size of equity increases (H1a). Owners who lose more control for a given equity increase face a cost component in addition to the required return on the new equity - the cost of losing influence. This makes equity increases less attractive. Second, it is hypothesised that potential loss of control is positively related to the leverage of companies (H1b). Companies where existing owners would lose more control in an expansion will rely more extensively on

\footnotetext{
${ }^{1}$ There is also an argument that overlending occurs (see, for example, de Meza and Webb (1987) and de Meza (2002)).
} 
bank financing and will therefore have higher leverage than otherwise comparable companies. Owners are prepared to pay higher interest rates for additional loans in order to stay in control. Third, the relationship between potential loss of control and company growth is anticipated to be negative (H2). This is a consequence of the first two hypotheses. Some growth opportunities become unprofitable, if they are financed with debt in a situation when debt levels are already high. Even if the returns of the growth opportunity exceed the cost of equity capital, equity finance may not be used, because a control premium is demanded. Fewer growth opportunities will be realised as a result, and company growth will be smaller.

To study these effects, information on private UK companies with limited liability is used. The dataset comprises 8,964 companies and covers the years 1997 to 2001. Private companies are used because their ownership is typically more concentrated than that of public companies. Owners of companies with dispersed ownership do not suffer a loss of control in an equity expansion, because they have negligible influence to start with. There are also public companies with concentrated ownership but because private and public companies are different in many respects, it would be difficult to combine them in one analysis.

For the identification of the effect of potential loss of control on company characteristics, it is important to deal with two related econometric problems. First, for the econometrician it is not possible to observe whether companies have growth opportunities and yet do not use them, as the owners want to stay in control. It is only possible to work with proxies for growth opportunities, but the proxies themselves are typically influenced by decisions taken by the owners or managers. For example, expenditure on R\&D is often used as a measure of growth opportunities. However, an owner who wants to stay in control would not undertake R\&D in the first place, even if possibilities to expand existed. Second, it is not possible to directly investigate the relationship between loss of control due to actual ownership changes and the dependent variable of interest, because actual ownership changes are inherently endogenous. For example, an owner would only give up control if he had profitable growth opportunities. It would therefore not be surprising to find that companies in which the largest owner lost control are growing faster.

One way of dealing with the above-mentioned problems is to work with hypothetical equity increases that are the same for all companies. This mitigates the endogeneity problem and does not require a good measure of growth opportunities. The loss of control resulting from 
the hypothetical equity increase needs to be quantified and can then be used in the regression analysis. Section 3 of this paper gives a detailed description of how potential loss of control is calculated.

The empirical results confirm the expected effects of potential loss of control. Companies in which the largest owner would lose more influence in the face of an equity increase have smaller equity increases, are more highly levered and exhibit slower growth than comparable companies.

The remainder of the paper is organised as follows. Section 2 gives an overview of the related literature. Section 3 covers the measurement of potential loss of control. Section 4 highlights important institutional details of private companies in the UK. Section 5 explains the dataset. Section 6 presents the empirical analysis. Finally, section 7 concludes.

\section{Related Literature}

\subsection{Theoretical Background}

What are private benefits of control? Although the theoretical literature has analysed the effects of the private benefits of control, there is rarely a specific analysis of the sources of the benefits. In general, benefits can be divided into two categories: pecuniary and nonpecuniary. The pecuniary benefits can be a managerial salary that is higher than the market rate or perks that can be taken, for example, an expensive company car. The non-pecuniary benefits can be even more important than the pecuniary ones. They include the prestige and social status that comes with ownership as well as the power to decide on the business strategy of the company and independence from superiors. Non-pecuniary benefits can be especially strong if the owner is the founder of the company or if the company has been controlled by the owner's family for a long time, because then the relationship between owner and company is closer.

There are two main ways in which private benefits are modelled. One strand of the theoretical literature assumes that private benefits reduce company resources and are costly to extract, i.e. for each pound of private benefits enjoyed, the company's value decreases by more than one pound. This fits well for private benefits that are mainly pecuniary (e.g., Burkart et al. (1998); Bennedsen and Wolfenzon (2000)). A second strand models private 
benefits as existent in addition to monetary benefits. Their enjoyment is not using up company resources (e.g., Aghion and Bolton (1992); Zwiebel (1995)). This approach captures more the non-pecuniary elements of private benefits since no costly diversion strategy is required. For private companies the non-pecuniary benefits seem to be more important, since all owners typically have a significant stake and are therefore informed about the situation of the company. No owner would allow other owners to divert substantial resources for private benefit.

How do the private benefits of control affect company characteristics? In the following, some recent contributions incorporating private benefits will be discussed. The model by Anderson and Nyborg (2001) is probably most closely related to the empirical analysis in this paper. It sheds light on how the choice of financing and growth of a company are related. The companies are characterised by a contracting inefficiency that allows insiders to divert cash flow for their private benefit, i.e. the model assumes pecuniary benefits of control. In the first stage, an entrepreneur can do $R \& D$ and start a company. In the second stage, the company can either be financed with outside equity or with debt. If debt financing is chosen, the entrepreneur may remain in the position even if an outside manager could do the job better. If equity is chosen, the entrepreneur risks being replaced by a more able outside manager. It can be seen that equity promotes higher second stage growth than debt, but this advantage must be traded off against the disadvantage of reduced incentives to do R\&D in the first stage.

Cressy (1995) focuses on loss of control due to bank loans, leaving loss of control due to equity aside. It is assumed that the larger the bank loan is, the larger is the loss of control. Then, since the utility of entrepreneurs depends negatively on the size of the bank loans, companies will borrow less than is optimal. For some of the entrepreneurs the loss aversion diminishes over time; they start to borrow more and their companies grow.

A strand of the literature that is less directly related to this paper concerns models that analyse ownership structures after an original owner sells shares to obtain finance. Bebchuk (1999) looks at the choice between a concentrated and a dispersed ownership structure in the context of an IPO, when private benefits of control exist but are not necessarily costly to extract. He finds that larger private benefits tend to favour concentrated ownership, because by either keeping a controlling stake or by selling a controlling stake to one new owner, the 
original owner can enjoy the private benefits.

Bennedsen and Wolfenzon (2000) derive efficient ownership structures for the case where private benefits are costly to extract. The founder of the company can choose an ownership structure with several large shareholders. They find that for every possible constellation there is a one-share one-vote ownership structure that maximises efficiency. This is due to the alignment effect, from which it follows that the company value increases in the cash flow stake of the controlling coalition. They also derive a coalition formation effect which says that the coalition with the smallest cash flow stake wins, because it has the largest group of shareholders from whom to expropriate.

In sum, there are theoretical models that derive the implications of private benefits of control on company characteristics, but there is no model that brings out the hypotheses concerning the effect of private benefits on capital structure, equity issuance and company growth that are tested empirically in this paper.

\subsection{Previous Empirical Evidence}

Survey evidence shows the reluctance of many owners to make use of private equity or venture capital, because they do not want to lose control over their company. In a survey of private companies in the UK, Poutziouris et al. (1998) find that $50 \%$ of the owners would not consider issuing external equity. They indicate that 'maintaining control / keeping the company in the family' is one of their main business goals. This attitude was also found in a survey of Swedish small and medium-sized companies (SMEs) in which many owners indicated that they would rather sell the whole company than take on additional owners (Cressy and Olofsson (1997)).

Indirect evidence for the existence of non-pecuniary benefits in private companies has been provided by Moskowitz and Vissing-Jørgensen (2002). They find for the USA that equity holdings in private companies yield about the same return as equity holdings in public companies. However, the volatility of an index on private companies is, if anything, higher than the volatility of an index on public companies. Given that households are typically not well diversified in private equity, it is difficult to explain why households hold private equity at all if only the financial return is being considered. The authors suggest that non-pecuniary benefits of control might be one explanation. 
So far, there is no direct evidence on the size of the private benefits of control for private companies. For public companies the importance of private benefits can be inferred from the price differential in take-over contests between voting shares and non-voting shares (e.g., Lease et al. (1983); Zingales (1994)). Another possibility is to gauge private benefits from block trades of shares by looking at the difference between the price of a share in the block and the price of a share on the stock exchange. Barclay and Holderness (1989), for example, find that equity blocks of at least $5 \%$ of common stock trade at an average premium of $20 \%$ for a sample of 63 US block trades between 1978 and 1982. This suggests that there are private benefits that only accrue to holders of large blocks:2

\section{Measurement of Potential Loss of Control}

It is crucial for the analysis to find a measure that describes how much influence the existing owners would lose in an equity expansion. Influence is measured by means of a probabilistic voting model; more specifically, the measure of influence is the probability of winning a vote for the largest owner in a yes-no decision that is taken with a simple majority. The measure for a decrease in influence is therefore the difference between the probability that the largest owner will win a vote given the current ownership structure and the probability that the largest owner will win a vote in a new ownership situation after a hypothetical equity increase. The difference between the two probabilities is termed 'potential loss of control'. For the calculation of the measure it is assumed that all owners vote independently of each other with equal probability for or against the largest owner. It is now possible to calculate the probability that the largest owner will win by considering all possible voting patterns. Cubbin and Leech (1983) used this probabilistic voting model to identify the influence of shareholders in UK public companies ${ }^{3}$

\footnotetext{
${ }^{2}$ For more recent analyses of the private benefits of control see, for example, Nicodano and Sembenelli (2000) and Dyck and Zingales (2002).

${ }^{3}$ Cubbin and Leech (1983) developed a formula to calculate approximate probabilities in the case of many owners with this voting model. For this analysis, it is possible to calculate the exact probabilities, because the number of owners is smaller in private companies. Felsenthal and Machover (1998, p. 36; p. 171f.) discuss the interpretation of measures of voting power. The Banzhaf measure reflects voting power as the degree to which an owner's vote is able to influence the outcome of a decision; and the Shapley-Shubik measure reflects
} 
For the equity increase it is assumed that all but the largest owner increase their stake. Here the idea is that the largest owner is more likely than the others to be wealth constrained, because the largest owner has already a considerable investment in the company. First, an equity increase of $10 \%$ is considered, because this volume is the most prevalent in the sample. Second, an average loss of control measure is calculated that considers different volumes of equity increases with the relative frequency in which they occur in the sample ${ }^{4}$ The two measures, calculated under the assumption that each owner votes individually, are denoted by Ind_10 for the $10 \%$ increase and by Ind_avg for the average of different sizes of equity increases, respectively $5^{5}$

A short example should help clarify the measure. Consider a company with three owners of which the largest owner holds $40 \%$ of the equity, the second largest $35 \%$, and the smallest $25 \%$. In a vote, the largest owner will always vote 'yes' and the other two owners vote independently of each other. There are four cases to consider. First, all three owners vote 'yes' and the largest owner wins the vote. Second and third, only one of the smaller owners votes 'yes' but the largest owner nevertheless wins the vote. Fourth, both smaller owners vote 'no' and the largest owner loses the vote. It follows that the largest owner has a $75 \%$ probability of winning a vote. The probability of winning can be calculated in the same fashion after a hypothetical change in ownership.

Because family ownership is very common for private companies, it is worth trying to incorporate family structures into the voting behaviour as a robustness check. It is possible that family members have the same opinion on company matters and therefore vote most of the time together. However, it could also be that family quarrels lead to family members expressing opposing views. In order to model family voting behaviour, it is assumed that all owners with identical last names belong to one family and that members of one family

voting power as the expected payoff that an owner gets from a fixed prize that is allocated to the winning coalition. Leech (2002) finds that the Banzhaf measure reflects variations in the power of shareholders of British listed companies better than the Shapley-Shubik measure. The measure used here is a linear function of the Banzhaf measure. It was, among others, also used by Nickell et al. (1997)

${ }^{4}$ The relative weights are 0.71 for a $10 \%$ increase, 0.1 for a $30 \%$ increase, 0.07 for a $50 \%$ increase, 0.03 for a $70 \%$ increase and 0.09 for a $90 \%$ increase.

${ }^{5}$ As a robustness check the potential loss of control was calculated for the case that equity is increased by an additional owner who enters the company. The results were very similar. 
vote as one bloc, i.e. all members of a family vote either 'yes' or 'no'. This is one of several possibilities to model family voting behaviour, but it has a specific advantage. It is possible that some owners transfer part of their ownership to their spouse for tax reasons. The decision on how to vote the shares remains, however, with the original owner, i.e. own and transferred shares are voted identically. The potential loss of control measure incorporating family structures takes this possibility into account. Again, a 10\% equity increase (Fam_10) and a weighted average of different sizes of equity increases (Fam_avg) are considered. $]^{6}$

The measure of potential loss of control has specific strengths and weaknesses. An advantage of this measure is that it takes the whole distribution of ownership into account, i.e. it has different values depending on whether the remaining shares are dispersed or concentrated. For example, if the largest owner is the only one with a substantial stake and the other owners hold only a negligible investment, then the largest owner will have much more influence than when faced with only a few other owners, who also have a large number of shares.

This measure can best be viewed as a reflection of a priori voting power that abstracts from particular personalities and ignores affinities or disaffinities between voters. It is important to recognise that independent voting is part of the definition of the extent of control, not an assumption about how the world works.

A potential limitation of this measure is its focus on the effect of an equity expansion on the largest owner. This implicitly assumes that the largest owner is influential in decisions regarding the capital structure, equity issuance and growth. Although this need not be the case in every company, it can be regarded as a good first approximation.

Potentially, there are other measures that could be used as an approximation for loss of influence in a hypothetical equity increase. The ownership share of the largest owner is a possibility. However, for decisions taken by simple majority it does not matter whether the largest owner is marginally or significantly above $50 \%$, a point that is not reflected by this measure. The use of the part of the largest owner's share that exceeds $50 \%$ is also problematic. This could be seen as a measure for a buffer zone, reflecting how much ownership the largest owner could give up before losing influence. However, once the ownership falls below

\footnotetext{
${ }^{6}$ Restricted by the information available in the dataset, a company is defined to be in family ownership, if two or more owners have the same last name. This is the case for $44 \%$ of companies in the sample.
} 
$50 \%$, the distribution of shares among all other owners becomes of crucial importance for the amount of influence the largest owner would lose.

A measure of potential loss of control derived from hypothetical ownership changes is used in this analysis in order to mitigate the problem of endogeneity. This problem is encountered when looking at actual ownership changes. One could try to measure the loss of control afflicting the largest owner after an actual increase of equity. This could be related to company growth after the change. To the extent that companies with ownership changes grow faster than other companies with the same characteristics in the same industry, one would have a measure of the reward required for relinquishing control. However, since only companies with good growth opportunities would consider issuing new equity, a problem of reverse causality would be encountered. Of course, one could try to find instruments for the actual loss of control. It would, however, be extremely difficult to find a variable that is related to the decision of owners to give up control, but not to resulting company characteristics such as the capital structure or the company's growth. Furthermore, the use of actual ownership changes would not allow us to investigate how private benefits of control affect the leverage of a company, because, by an accounting identity, all increases in equity will lead to a reduction in leverage.

It can be argued that the potential loss of control measure does not solve the endogeneity problem completely. The measure is a function of the ownership structure, and if the ownership structure is endogenous, so will be potential loss of control. However, by analysing hypothetical and not actual ownership changes this problem is reduced. It would still be desirable to instrument potential loss of control, but no suitable instruments are available.

\section{Institutional Details}

\subsection{Voting Rights}

In order to determine the probability that the largest owner will win a vote, it is necessary to know the percentage of votes held by each owner. This task is complicated by the fact that private limited companies can have several classes of shares and voting rights can vary according to share class. However, many companies have only one class and, in general, the smaller a company is, the fewer share classes it has. 
For the calculation of voting rights, the most important distinction is between ordinary and preference shares. Ordinary shares confer voting rights and the right to obtain a dividend should one be declared. Preference shares, on the other hand, usually have no voting rights attached, and the owners are not directly involved in decisions concerning the company's affairs. To make up for this disadvantage, preference shares have the right to a fixed dividend. Owners of ordinary shares only obtain a dividend if the amount distributed is sufficient to satisfy the claims of the owners of preference shares. Preference shares are typically cumulative, which means that skipped dividends of previous years must be made up as soon as dividend payments are resumed. For example, an owner of a $7 \%$ preference share would have a right to a payment of $14 \%$ of the nominal value of the share should dividends have been skipped once. Preference shares often become voting shares should no dividend be paid over a specified number of years.

The dataset allows us to differentiate between ordinary and preference shares. For this analysis, ordinary shares are treated as voting shares and preference shares are treated as non-voting shares. In rare cases, the voting rights could be arranged differently.

One might think that the issuance of non-voting equity is a possible way to raise funding without losing control, because voting rights remain concentrated with the original owners. Although this mode of financing avoids costs related to loss of control, there are other disadvantages to be considered. It is difficult to find investors who are willing to invest money without having any influence on company strategy. If owners are willing to do it, then they will need to be compensated by higher expected dividend payments, which makes this form of financing expensive 7 The empirical analysis will separately control for the potential loss of control and the use of preference capital.

\subsection{Decision Making}

Owners of private companies come together in annual general or extraordinary meetings to decide on company matters. Decisions are normally passed with a simple majority. However, the Companies Act lists a few decisions that require a $75 \%$ majority or indeed unanimity. In the Articles of Association, the owners can also agree to have stricter majority requirements

${ }^{7}$ The optimality of one-share one-vote was studied by Grossman and Hart (1988) and Harris and Raviv (1988) in the context of public companies faced by take-over threats. 
for some decisions than are prescribed by the Companies Act.

Most decisions are taken by ordinary resolutions, which require a 50\% majority. For example, they are used to increase share capital or to give authority to the directors to allot shares. Ordinary resolutions are used for all matters unless the Articles of Association or the Companies Act require another type of resolution. Extraordinary resolutions require a majority of $75 \%$. These are necessary to modify the rights of classes of shareholders or for winding-up a company. Special resolutions, also requiring a $75 \%$ majority, are used for important matters such as alterations to the Memorandum or to the Articles of Association as well as for reductions of capital. There are also elective resolutions that must be passed by unanimous agreement. These resolutions are used to amend the duration of the authority of directors to allot securities or to dispense with the holding of annual general meetings.

Since ordinary resolutions are the most common type, this analysis will concentrate on them and will use a $50 \%$ majority requirement to determine the probability of winning for the largest owner. Furthermore, for a 75\% majority requirement a different measure of control would be necessary. It is not sufficient to take into account that $75 \%$ of the votes are required to pass a decision. One also needs to consider that to preserve the status quo, only one vote above $25 \%$ is required 8

\section{Data}

The database FAME (Financial Analysis Made Easy), distributed by Bureau van Dijk, is used as the basis for the analysis. It includes all companies in the UK that satisfy at least one of the three following criteria: a turnover higher than $£ 750,000$, a pre-tax profit higher than $£ 45,000$, or shareholder funds greater than $£ 750,000$.

The detail of the information available in FAME depends on the publication requirements, since only publicly available information can be included. In the UK all companies with limited liability are required to deposit their accounts with Companies House, so that their trading partners and the general public can inquire. The specific publication requirements depend on the size of the company.

\footnotetext{
${ }^{8}$ The information on institutional details in this section are taken from the Companies Act 1985 and 1989 (Dey (1994)) and from the internet site of Companies House (www.companieshouse.gov.uk).
} 
The database provides information on financial data from balance sheets and from profit and loss accounts for the years 1989 to 2001. However, information on owners and directors is only provided from the year 1997 onwards. This restricts the time period covered by the analysis to the years 1997 to 2001. Since the database contains only the current ownership structure and the current directors, it was necessary to extract information from older versions of the database to construct time-series for the variables relating to this information.

The dataset used for this analysis includes companies that went out of business between 1997 and 2001. Companies that changed their legal form from private with limited liability (Ltd) to public with limited liability (PLC) are, however, not covered. This is a limitation of the analysis, since companies that change the legal form have probably better than average growth opportunities 9

Only independent companies are included into the dataset, because a company that is $100 \%$ owned by another company has no direct owner who would care about control. Also, independent companies whose largest owner is a company or neither a company nor an individual (e.g. a trust or a fund) are excluded. These types of owners will not have an interest in control comparable to that of individuals. Companies from the financial sector, i.e. in financial intermediation and insurance, are also excluded since their capital structure will differ systematically from the capital structure of the rest of the companies. Furthermore, the $1^{\text {st }}$ and the $100^{\text {th }}$ percentile of financial ratios and growth rates have been deleted, because they contained implausibly large or small values. All reported results in this paper relate to the trimmed sample.

Table A in the appendix provides, for easy reference, the structure of a private company's balance sheet. The definitions for all the variables used are listed in table $\mathrm{B}$ and $\mathrm{C}$, also in the appendix. Most variable names explain themselves, but some concepts should be emphasised. It is important to note that the term 'equity', as employed here, refers to the issued capital, i.e. to the nominal value of the shares. It does not include accumulated profits. Therefore, all observed equity increases are due to an issuance of additional shares.

'Preference ratio' is the ratio of preference capital to total equity capital. Preference

\footnotetext{
${ }^{9}$ It should be noted that merger and acquisition (M\&A) activity is not important for the results. With the use of the Zephyr database, distributed by Bureau van Dijk, the companies engaging in M\&A have been identified. The results are not affected when those companies are excluded from the analysis.
} 
capital is equity capital that is not vested with voting rights. The 'capital expenditure ratio' is the ratio of capital expenditure and other investments to total assets. It is used as a proxy for growth opportunities in the analysis.

\section{Empirical Analysis}

\subsection{Stylised Facts}

This subsection provides a short overview of the main characteristics of the companies, their growth and their financing patterns. It also presents additional information on the potential loss of control measure.

The following table 1 gives an indication of the considerable importance of small and medium-sized companies for the UK economy in 2002. Small and medium-sized companies (here defined as having fewer than 250 employees) account for more than $50 \%$ of employment and turnover 10

Table 1: Relative Importance of Companies in Different Size Classes (2002)

\begin{tabular}{|l|c|c|c|c|}
\hline & Micro & Small & Medium & Large \\
\hline Number of Employees & $0-9$ & $10-49$ & $50-249$ & $250+$ \\
\hline \hline Number of Businesses (in \%) & 94.6 & 4.4 & 0.7 & 0.2 \\
Employment (in \%) & 29.4 & 14.3 & 11.9 & 44.4 \\
Turnover (in \%) & 22.0 & 15.0 & 15.0 & 48.0 \\
\hline
\end{tabular}

Source: Small Business Service (2003)

Note: Some figures do not equal 100 due to rounding.

Table $\mathrm{D}$ in the appendix presents full descriptive statistics of the companies that are included in the sample. One can see that the companies are relatively small; the median number of employees being 53, whereas the mean is 130 .

In contrast to public companies, private companies are generally characterised by a limited

\footnotetext{
${ }^{10}$ It would also be interesting to know the relative share of private companies with limited liability concerning employment and turnover. Unfortunately, this information does not seem to be available for the UK.
} 
number of owners. The average company in the sample has 2.7 owners and companies with more than ten owners are exceptional. The full distribution of the number of owners is given in figure $\mathrm{A}$ in the appendix.

Figure B in the appendix displays the relationship between the average share of the largest owner and the age of the company. In fact, the share first increases and then decreases. The increase, in the beginning, can be caused by some owners buying out others while the company is still relatively young and is maybe in some difficulties. For companies over 30 years old, the share of the largest owner decreases, presumably due to expansion and ownership splits after the death of previous owners.

The distribution of the share of the largest owner has two mass points. There is only one owner with $100 \%$ ownership in about $27 \%$ of the companies, and in about $18 \%$ of the companies the largest owner has exactly $50 \%$ of all shares.

The development of leverage as the companies get older gives insight into the dynamics of the capital structure. This information is presented in figure $\mathrm{C}$ in the appendix. Companies in the lowest age category, from one to nine years, have the highest leverage of about $70 \%$. This number decreases continually till the companies reach the age range of 50 - 59 years and then stabilises at around $40 \%-45 \%$. This pattern shows the importance of internal finance in the growth process of companies. As companies get older, they can rely more heavily on retained profits as a source of financing, and consequently leverage decreases. It can also be interpreted as an aversion to bank finance. Companies need bank finance to start, but they try to reduce their exposure over time.

In order to judge the implications of a possible negative effect of potential loss of control on equity increases, it is necessary to know if fast growing companies use equity more extensively as a means of finance compared to slow growing companies. Table 2 gives mean and median growth rates for total assets and financing choices. Internal financing refers to the sum of the profit and loss account (retained earnings), revaluation reserves and other reserves. In the sample period 1997 to 2001, companies use all three types of financing - namely increases in equity, increases in liabilities and increases in internal financing. Companies that grow faster than the median company with respect to total assets also increase their equity more, but the median equity increase is still zero. This shows that faster growing companies make more use of equity financing. 
Table 2: Financing Choices

\begin{tabular}{|l|c|c|c|c|}
\hline & \multicolumn{2}{|c|}{ All Companies } & \multicolumn{2}{c|}{ Only Fast Growing Companies } \\
\hline \hline & Mean & Median & Mean & Median \\
\hline \hline Growth in total assets (in \%) & 6.4 & 4.1 & 19.1 & 13.9 \\
\hline Growth in equity (in \%) & 0.07 & 0 & 0.24 & 0 \\
Growth in liabilities (in \%) & 6.1 & 2.1 & 23.0 & 16.5 \\
Growth in internal financing (in \%) & 9.9 & 7.2 & 17.4 & 12.3 \\
\hline
\end{tabular}

Note: Number of observations is 13,125 . The subgroup 'only fast growing companies' contains only companies that grow faster than the median company with respect to total assets. This table is based on fewer observations than the regressions, since growth rates for all types of financing need to be observed. Annual growth rates are reported.

Figures $\mathrm{D}$ and $\mathrm{E}$ in the appendix allow a better understanding of the potential loss of control measures by plotting them with respect to the share of the largest owner. It can be seen that potential loss of control is especially high for medium-sized ownership shares. If the largest owner holds a share that is sufficiently above $50 \%$, then potential loss of control is equal to zero, because the owner has full control before and after the hypothetical equity increase.

In many instances of the hypothetical ownership change the largest owner does not lose any control. If all but the largest owner increase their stake by $10 \%$ (Ind_10), then the largest owner will not lose any control in $63 \%$ of cases. The respective value for the measure considering an average of different volumes of equity increases (Ind_avg) is 37\%.

\subsection{Effect on Growth in Equity}

This subsection presents the test of hypothesis $H 1 a$ by relating the potential loss of control to the size of the equity increase. A negative relationship is expected, because owners who lose more control for a given equity increase find equity increases more costly. In the sample, the equity growth rate is zero for the vast majority of observations. Only $3.8 \%$ of observations have a positive growth rate, and $4.4 \%$ of observations have a negative growth rate. From a theoretical point of view there is no prediction on the relationship between potential loss of control and equity decreases. Therefore only companies with a zero or positive growth rate in equity have been chosen for this analysis. In order to get unbiased results, a tobit model 
with robust standard errors is used.

The dataset covers the time period 1997 to 2001, but on average a company is observed for less than three years. Some companies went into or out of business during the sample period and, over time, more companies have been covered in the ownership section of the database. Because the information on the time-series dimension is very limited, the tobit regression is done as a pooled time-series cross-section analysis. The standard errors are corrected to allow for heteroscedasticity and auto-correlation of the observations pertaining to one company. Since there is persistence in the characteristics of companies, it is likely that the error terms from observations relating to one company are correlated.

As can be seen from table 3 , there is a clear indication that potential loss of control has a negative effect on the size of equity increases, which is consistent with hypothesis H1a. This table shows full regression results for the two potential loss of control measures Ind_10 and Ind_avg. The results for the measures that take the family structure into account (Fam_10 and Fam_avg) are very similar and therefore only presented in abbreviated form. Potential loss of control has a negative coefficient that is significant to at least the $5 \%$ level for the assumption of individualistic voting. For the assumption of family voting the coefficient is negative but not significant. The effect is also of high magnitude. As calculated for regression (a), the marginal effect for the unconditional expected value of equity growth (zero or positive growth rate) is -0.64 . Using this marginal effect, an increase of potential loss of control of one standard deviation leads ceteris paribus to a decrease in equity growth of 0.1 percentage points. This effect is larger if only companies with equity increases are considered. The marginal effect conditional on being uncensored (positive growth rate) is -2.52 . This translates into a decrease of the equity growth rate of 0.4 percentage points for a one standard deviation increase of potential loss of control ceteris paribus ${ }^{11}$

To identify the influence of the private benefits of control, it is necessary to control for other characteristics of the ownership structure that could have an influence on the dependent variable. As further control, the ownership share of the largest owner is included. Since the appropriate functional form was unknown, this variable was first included as a polynomial of order four. The highest power was then dropped, if it wasn't significant to at least the $10 \%$ level. Ultimately, only the linear term was kept.

\footnotetext{
${ }^{11}$ Conditional on positive equity growth, the mean growth rate is $20.2 \%$ and the median is $4.8 \%$.
} 
Table 3: Effect on Growth in Equity

Dep. Variable: Non-negative Growth Rate Equity (in \%)

\begin{tabular}{lcc}
\hline \hline & $(\mathrm{a})$ & $(\mathrm{b})$ \\
\hline Potential loss of control & $-20.48^{* * *}$ & $-19.93^{* *}$ \\
Share largest owner & $(8.01)$ & $(8.36)$ \\
& $-9.17^{* *}$ & $-9.40^{* *}$ \\
Dummy largest owner manager & $(4.04)$ & $(4.09)$ \\
& $-11.14^{* * *}$ & $-11.32^{* * *}$ \\
Leverage & $(2.14)$ & $(2.14)$ \\
Preference ratio & $27.28^{* * *}$ & $27.14^{* * *}$ \\
& $(4.67)$ & $(4.67)$ \\
First lag ROA & $16.89^{* *}$ & $16.99^{* *}$ \\
Wald test, $\chi^{2}(58)$ & $(8.32)$ & $(8.32)$ \\
Ln employees & -15.07 & -15.21 \\
Ln age & $(12.06)$ & $(12.06)$ \\
Equity & $3.99^{* * *}$ & $4.02^{* * *}$ \\
& $(0.764)$ & $(0.764)$ \\
& $-8.28^{* * *}$ & $-8.23^{* * *}$ \\
& $(1.53)$ & $(1.53)$ \\
& 1.27 & 1.27 \\
& $(0.781)$ & $(0.784)$ \\
\hline
\end{tabular}

\begin{tabular}{lcc}
\hline Abbreviated further regression results: & $(\mathrm{c})$ & $(\mathrm{d})$ \\
\hline Potential loss of control & -10.17 & -5.50 \\
& $(8.67)$ & $(8.60)$ \\
\hline \hline
\end{tabular}

Note: $* * *, * *, *=$ significant on the 1,5 and 10 percent level. Tobit estimation considering non-negative growth rates of equity. 980 observations are uncensored (larger than zero), 24,380 observations are censored (equal to zero). The regressions differ according to the potential loss of control measure used. The regressions shown in full refer to individualistic voting; regression (a) employs Ind_10 and regression (b) Ind_avg. The abbreviated results refer to family voting; (c) employs Fam_10 and (d) Fam_avg. The regressors are expressed as ratios. Robust standard errors allowing for heteroscedasticity and autocorrelation are in parentheses. The regressions contain industry and year dummies as well as their interaction terms. 
In around three quarters of the companies, the largest owner is also a manager. In this case, the ownership share of the largest owner proxies for the incentive to exert effort in managing the company. If the largest owner is not a manager, then the ownership share proxies for the intensity of monitoring. Larger owners have a better incentive to monitor, because they reap a higher proportion of the gains from monitoring. Their decisions are less affected by the possibility of free riding. In an exploratory specification, the ownership share was interacted with the dummy for the largest owner being a manager. Since the difference of the two effects was not significant, results are shown without the interaction term.

From the negative coefficient of share of the largest owner, it can be concluded that better incentives to exert effort or better incentives to monitor lead to smaller equity increases. It could be that empire building, i.e. growing the company above a level that maximises value, can be prevented.

A dummy that equals one if the largest owner is at the same time manager is also included. The significant negative coefficient shows that equity increases are smaller, if the largest owner is at the same time manager. This could also be an indication that empire building is prevented.

Two controls for the company's capital structure are included: leverage and the preference ratio (ratio of preference capital to total equity capital). The regression shows that companies with higher leverage rely more on equity financing. The positive effect of leverage is consistent with the pecking order theory (Myers and Majluf (1984)). Companies will use debt financing until their debt capacity is reached, only then will they issue new shares. The proceeds of an equity increase can be either used to finance future growth or to reduce leverage. Pagano et al. (1998), for example, find that Italian companies used the proceeds of an initial public offering mainly to reduce leverage.

The preference ratio shows the extent of the use of preference capital. The use of preference capital gives an indication of the control aversion of owners since it allows the raising of equity without losing control. It is also an expensive form of financing since the shareholders need to be compensated for their lack of influence on company strategy through higher dividends. The positive influence of this variable on equity increases is difficult to interpret, because it is not possible to observe whether the equity increase relates to ordinary or preference stock. However, most equity increases will concern ordinary stock, since only $4.4 \%$ of the companies 
in the sample use preference capital ${ }^{12}$ The positive influence can therefore indicate that companies with a high preference ratio have exhausted their ability to issue non-voting stock and are forced to issue ordinary stock.

Past profitability has no effect on equity increases. This could be because past profitability has two conflicting effects on equity growth. First, companies that were successful in the past will have accumulated retained earnings and don't need to rely on equity finance. Second, if success if persistent, then profitable companies have more growth opportunities and require more capital to expand. Neither of the effects is dominant in the regression.

The regression also includes two controls for company size. Size measured as the natural logarithm of the number of employees has a significant positive effect on equity increases. The absolute amount of equity is also related to size. It is included to control for any level effects. This variable is not significant in the current specification, but it has a significant positive effect once the natural logarithm of the number of employees is excluded. Older companies have smaller equity increases. One reason could be that retained earnings are sufficient for the investment needs.

As a robustness check, the effect of potential loss of control on the probability of an equity increase was tested with a probit regression (not reported). The dependent variable is equal to one for equity increases and equal to zero for no changes in equity. Potential loss of control has a significant negative influence on the probability that an equity increase is observed. Also, the coefficients of the other regressors keep their sign and significance level. As in the tobit regression, observations with negative equity growth rates have been disregarded.

To summarise, the results of this subsection show strong evidence for the negative influence of potential loss of control on the size of equity increases. Overall, the results are consistent with hypothesis $H 1 a$.

\subsection{Effect on Leverage}

Table 4 presents the results for the leverage equation. Consistent with hypothesis $H 1 b$, potential loss of control has a positive influence on leverage. Owners who want to stay in control prefer to use debt more extensively than owners who are not confronted with a

\footnotetext{
${ }^{12}$ The preference ratio, i.e. the ratio of preference capital to total equity capital, is quite high for companies that use preference capital. Its mean is $40.7 \%$ whereas its median is $35.7 \%$.
} 
potential loss of control. In order to stay in control, they may accept paying a higher interest rate to obtain further loans. The results are significant to the $1 \%$ level for all potential loss of control measures. The economic significance of this effect is also not negligible. For regression (a) it has been calculated that a one standard deviation increase of potential loss of control increases leverage ceteris paribus by 0.96 percentage points.

This specification contains more observations than the previous one explaining equity growth. Here all companies are included, whereas the equity growth specification excluded companies for the years in which they had negative equity growth.

The share of the largest owner has a positive influence on leverage 13 The size of the ownership share can be used to signal company quality to banks. The owner is only willing to invest a large amount of private wealth, when convinced of the quality of the company. Banks may give more loans to companies that have at least one large owner. This reasoning relates to the work of Leland and Pyle (1977) who made a similar argument about the ownership share of managers. The positive effect of the largest owner being at the same time manager can have a similar interpretation. The additional commitment of the largest owner increases the debt capacity of the company.

The regression also includes a control for the use of preference capital. The results show that a higher preference ratio is related to higher leverage. This is consistent with the view that more excessive use of debt finance is a means for the original owners to keep control.

In regressions explaining leverage, it is common to control for growth opportunities. It is, however, difficult to find a good measure of growth opportunities for private companies. For public companies, the market to book value is commonly used. However, it is not available for private companies, since there is no observable market value. $R \& D$ expenditure is a further frequent choice, but it is not available in the dataset. For this analysis the capital expenditure ratio (ratio of capital expenditure to total assets) is chosen. Companies with good growth opportunities will in general invest more in machinery and equipment than other companies. The coefficient of this variable shows that companies with more growth

\footnotetext{
${ }^{13}$ This specification was also first estimated with the ownership share of the largest owner included up to its fourth power. The third power was significant, but since the cubic form showed a positive relationship over the relevant range, the specification with only the linear term is shown. This makes the results better comparable across the three subsections. The results of the other regressors were not affected.
} 
Table 4: Effect on Leverage

Dep. Variable: Leverage (in \%)

\begin{tabular}{|c|c|c|}
\hline & (a) & (b) \\
\hline \multirow[t]{2}{*}{ Potential loss of control } & $6.81^{* * *}$ & $6.63^{* * *}$ \\
\hline & $(1.48)$ & $(1.57)$ \\
\hline \multirow[t]{2}{*}{ Share largest owner } & $4.32^{* * *}$ & $4.39 * * *$ \\
\hline & $(0.885)$ & $(0.904)$ \\
\hline \multirow[t]{2}{*}{ Dummy largest owner manager } & $3.66^{* * *}$ & $3.72^{* * *}$ \\
\hline & $(0.455)$ & $(0.455)$ \\
\hline \multirow[t]{2}{*}{ Preference ratio } & $5.95^{* * *}$ & $5.90^{* * *}$ \\
\hline & $(1.71)$ & $(1.71)$ \\
\hline \multirow[t]{2}{*}{ Capital expenditure ratio } & $-6.19^{* *}$ & $-6.21^{* *}$ \\
\hline & $(2.92)$ & $(2.92)$ \\
\hline \multirow[t]{2}{*}{ First lag ROA } & $-64.7^{* * *}$ & $-64.6^{* * *}$ \\
\hline & $(2.29)$ & $(2.29)$ \\
\hline \multirow[t]{2}{*}{ Ln employees } & $2.80^{* * *}$ & $2.79^{* * *}$ \\
\hline & $(0.177)$ & $(0.177)$ \\
\hline \multirow[t]{2}{*}{ Ln age } & $-11.04^{* * *}$ & $-11.07^{* * *}$ \\
\hline & $(0.307)$ & $(0.306)$ \\
\hline Number of observations (companies) & $26,522(8,964)$ & $26,522(8,964)$ \\
\hline $\mathrm{R}$ squared & 0.23 & 0.23 \\
\hline Abbreviated further regression results: & (c) & $(d)$ \\
\hline \multirow[t]{2}{*}{ Potential loss of control } & $11.12^{* * *}$ & $9.66^{* * *}$ \\
\hline & $(1.73)$ & (1.78) \\
\hline
\end{tabular}

Note: $* * * * * *=$ significant on the 1,5 and 10 per cent level. OLS estimation. The regressions differ according to the potential loss of control measure used. The regressions shown in full refer to individualistic voting; regression (a) employs Ind_10 and regression (b) Ind_avg. The abbreviated results refer to family voting; (c) employs Fam_10 and (d) Fam_avg. The regressors are expressed as ratios. Robust standard errors allowing for heteroscedasticity and autocorrelation are in parentheses. The regressions contain industry and year dummies as well as their interaction terms. 
opportunities, i.e. a higher ratio, have lower leverage. This result is consistent with the theory on underinvestment as described by Myers (1977) which concludes that companies with many growth opportunities should use less leverage.

The control for past profitability shows that profits are partly used to reduce leverage. This observation is consistent with an aversion to losing control to banks. 14

The positive influence of size on leverage can be attributed to a more stable cash flow stream and therefore a higher debt capacity for larger companies. Age has a negative effect on leverage because retained profits become more important over time, increasing shareholders funds and reducing leverage. This was already shown in figure $\mathrm{C}$ in the appendix.

\subsection{Effect on Company Growth}

The third specification is concerned with the explanation of company growth. In general, company growth is volatile, fluctuating from one year to the next depending on the market conditions the company is confronted with. This makes it more difficult to identify the influences on company growth. In order to reduce the noise in the dependent variable, a growth rate that is averaged over a time period of four years (1998-2001) is chosen. The regressors refer to the beginning of the period (1998) 15 Consequently, ordinary least squares with standard errors that are robust to heteroscedasticity is an appropriate method to apply to the cross-section of observations.

Table 5 presents results on the testing of hypothesis $H 2{ }^{16}$ It can be seen that companies whose owners would lose more control in an expansion indeed grow more slowly. This is consistent with the hypothesis that owners who want to stay in control are willing to give up growth opportunities. The effect is negative and significant to at least the $5 \%$ level for all potential loss of control measures. The size of the effect, calculated for regression (a),

\footnotetext{
${ }^{14}$ There can also be an effect of reverse causality. If companies with high leverage need to pay higher interest rates, then profitability can be reduced. The results for the other regressors remain the same, when the first lag of return on assets is excluded.

${ }^{15}$ The results are qualitatively identical when the time period 1997-2000 is considered.

${ }^{16}$ The company growth regression covers fewer companies than the previous ones because not all companies are observed over this period. An estimation with a Heckman correction for attrition bias has therefore been employed. But since the error terms of the selection and the main equation have not been correlated, the results using the standard OLS technique are shown.
} 
is substantial. A one standard deviation increase in potential loss of control leads ceteris paribus to a 0.44 percentage points decrease in annual growth.

The share of the largest owner has a negative effect on company growth. As in the previous specifications, this variable was first included as a polynomial of order four. However, only the linear term showed ultimately a significant effect. The negative effect of the share of the largest owner is consistent with the argument that better incentives to exert effort or better incentives to monitor can prevent empire building. The dummy variable indicating whether the largest owner is a manager has no significant influence on company growth.

Leverage has a significant negative effect on growth, which is consistent with the pecking order theory (Myers and Majluf (1984)). A company with financial slack will take all profitable growth opportunities, but if only risky debt can be used, some growth opportunities will be passed up ${ }^{17}$ A negative relationship between leverage and growth is also found by Lang et al. (1996) for public companies. When splitting the sample into companies with high and low growth opportunities, however, they find the negative relationship only confirmed for companies with low growth opportunities.

This regression also includes a control for the use of preference capital. More extensive use of preference capital is related to slower growth. A high preference ratio is a sign that it is getting more difficult to issue additional preference capital. The alternative of issuing common (voting) stock is not attractive for owners who want to stay in control.

Controlling for past profitability shows that companies that were profitable in the past are likely to grow more in the future; a persistence of company success can be seen.

In addition, the size and age of companies have been controlled for. The regressions show no relationship between the size of a company and its subsequent growth. The age of a company, however, has a negative effect.

\footnotetext{
${ }^{17}$ It can be argued that leverage is endogenous in this regression. Companies in difficulties will have small growth rates and low profitability. Leverage can build up, if interest and capital cannot be serviced any more. This leads to an effect from small growth rates to high leverage. In this situation it would be appropriate to instrument leverage, but no good instruments are available. Therefore a specification without leverage was tested. The signs and significance levels of the other regressors remain the same.
} 
Table 5: Effect on Company Growth

Dep. Variable: Average Annual Growth of Total Assets, 1998-2001 (in \%)

\begin{tabular}{|c|c|c|}
\hline & (a) & (b) \\
\hline \multirow[t]{2}{*}{ Potential loss of control } & $-3.14^{* *}$ & $-3.44^{* *}$ \\
\hline & $(1.34)$ & $(1.45)$ \\
\hline \multirow[t]{2}{*}{ Share largest owner } & $-2.13^{* * *}$ & $-2.30 * * *$ \\
\hline & $(0.793)$ & $(0.826)$ \\
\hline \multirow[t]{2}{*}{ Dummy largest owner manager } & -0.472 & -0.493 \\
\hline & $(0.491)$ & $(0.490)$ \\
\hline \multirow[t]{2}{*}{ Leverage } & $-2.65 * * *$ & $-2.65 * * *$ \\
\hline & $(0.926)$ & $(0.926)$ \\
\hline \multirow[t]{2}{*}{ Preference ratio } & $-3.51^{* *}$ & $-3.53^{* *}$ \\
\hline & $(1.75)$ & $(1.75)$ \\
\hline \multirow[t]{2}{*}{ First lag ROA } & $21.94^{* * *}$ & $21.92^{* * *}$ \\
\hline & $(2.56)$ & $(2.56)$ \\
\hline \multirow[t]{2}{*}{ Ln employees } & 0.024 & 0.026 \\
\hline & $(0.150)$ & $(0.150)$ \\
\hline \multirow[t]{2}{*}{ Ln age } & $-0.862^{* * *}$ & $-0.851^{* * *}$ \\
\hline & $(0.268)$ & $(0.268)$ \\
\hline Number of observations (companies) & $4,377(4,377)$ & $4,377(4,377)$ \\
\hline $\mathrm{R}$ squared & 0.05 & 0.05 \\
\hline Abbreviated further regression results: & (c) & (d) \\
\hline \multirow[t]{2}{*}{ Potential loss of control } & $-6.12^{* * *}$ & $-5.69 * * *$ \\
\hline & $(1.76)$ & $(1.80)$ \\
\hline
\end{tabular}

Note: $* * * * * *=$ significant on the 1,5 and 10 per cent level. OLS estimation. The regressions differ according to the potential loss of control measure used. The regressions shown in full refer to individualistic voting; regression (a) employs Ind_10 and regression (b) Ind_avg. The abbreviated results refer to family voting; (c) employs Fam_10 and (d) Fam_avg. The regressors are expressed as ratios and refer to the year 1998. Robust standard errors allowing for heteroscedasticity are in parentheses. The regressions contain industry dummies. 


\section{Conclusion}

This paper studies the influence of private benefits of control on the issuance of new equity, leverage and company growth. It is hypothesised that companies in which existing owners would lose more influence in an expansion have smaller equity increases, use more debt and grow more slowly. Evidence supporting the predicted effects on the size of equity increases, leverage and company growth is found. The effect of loss of control on company growth is especially important in economic terms.

Overall, these findings are consistent with the view that there are demand side constraints of finance. These results also agree with previous survey evidence that highlighted the importance that owners attach to control (Cressy and Olofsson (1997); Poutziouris et al. (1998)). This paper takes the analysis a step further by showing that the owner's fear of losing control can affect company characteristics such as capital structure and growth.

These results have important implications for economic policy. The main implication is that it is important to differentiate between the demand and supply side constraints of finance. The UK government, for example, has started the 'Enterprise Investment Scheme' (EIS) in order to help small companies raise equity capital. This was in response to evidence that showed an equity gap for companies who want to raise moderate amounts of equity between $£ 100,000$ and $£ 500,000$. The scheme gives various tax advantages for individuals investing in a company with which they were previously unconnected (Bank of England, 2001). However, it seems that few companies are affected by supply side constraints of finance. Only $1.7 \%$ of the companies mentioned 'access to finance' as their main problem in the NatWest/SBRT Quarterly Survey of Small Business in Britain (NatWest/SBRT, 2002). The caution that emanates from this paper is that when observing companies that have growth opportunities but do not grow, one needs to be careful to consider both demand and supply side constraints. One should not immediately conclude that there is a market failure in the provision of equity capital. It is especially important to consider demand side constraints of finance when designing government programmes to support small and medium-sized companies.

The negative effect of loss of control on company growth has possible implications for the aggregate growth of economies. The fact that owners value control implies that their companies do not exploit all growth opportunities and therefore do not create as much employment 
and value added as they could. This can have an effect on aggregate growth, if some growth opportunities are idiosyncratic to a certain company, for example, if specific knowledge is required or if synergies with existing activities are necessary. Under such circumstances, it may not be possible for other companies to exploit the growth opportunities. 


\section{Appendix}

Table A: Balance Sheet of a Private Company

\begin{tabular}{l|l}
\hline Assets & Liabilities \\
\hline \hline Fixed assets & Current liabilities \\
Current assets & Long-term liabilities \\
& Shareholders funds \\
& $\bullet$ Issued capital \\
& $\bullet$ Total reserves \\
& $\circ$ Share premium account \\
& $\circ$ Profit and loss account \\
& $\circ$ Revaluation reserves \\
\hline Total assets & O Other reserves \\
\hline
\end{tabular}

Shareholders funds represent the book value of assets that belong to the shareholders. This position can be divided into the issued capital, which corresponds to the nominal value of the shares, and the total reserves. The components of the total reserves are: the share premium account (premium that was paid in excess of the nominal value of the shares at the issuance date), the profit and loss account (the accumulation of retained profits), the revaluation reserves (the upward or downward revaluation of assets), and other reserves.

The term 'equity' in this paper refers to the issued capital. 
Table B: Definition of Variables I

\begin{tabular}{|c|c|}
\hline Variable & Definition \\
\hline Equity (Issued capital) & Nominal value of issued shares \\
\hline Share largest owner & Ownership share largest owner \\
\hline Dummy largest owner manager & $\begin{array}{l}\text { Dummy equal to } 1 \text { if the largest owner is manager, } \\
0 \text { otherwise }\end{array}$ \\
\hline Leverage & $\begin{array}{l}\text { Ratio of the sum of current and long-term liabilities } \\
\text { to total assets }\end{array}$ \\
\hline Preference ratio & Ratio of preference capital to total equity capital \\
\hline Capital expenditure ratio & $\begin{array}{l}\text { Ratio of capital expenditure and other investments } \\
\text { to total assets }\end{array}$ \\
\hline $\mathrm{ROA}$ & Ratio of profit before taxes to total assets \\
\hline Ln employees & Natural logarithm of the number of employees \\
\hline Ln age & Natural logarithm of the age of the company in years \\
\hline Industry dummies & One digit level of the UK SIC code \\
\hline Time dummies & Year of the observation \\
\hline
\end{tabular}


Table C: Definition of Variables II

\begin{tabular}{|c|c|}
\hline Variable & Definition \\
\hline $\begin{array}{l}\text { Several potential loss of } \\
\text { control measures, variable } \\
\text { names listed below }\end{array}$ & $\begin{array}{l}\text { Potential loss of control incurred by the largest owner due } \\
\text { to a hypothetical equity increase. All owners but the } \\
\text { largest increase their stake. Overall, four measures are } \\
\text { employed: }\end{array}$ \\
\hline & $\begin{array}{l}\text { First, it is assumed that each owner votes individually. } \\
\text { Two measures of potential loss of control are calculated, } \\
\text { differing in the size of the equity increase. }\end{array}$ \\
\hline Ind_10 & Equity is increased by $10 \%$. \\
\hline \multirow[t]{2}{*}{ Ind_avg } & $\begin{array}{l}\text { Different volumes of equity increases are considered with } \\
\text { the relative weight that they have in the sample. } \\
\text { The relative weights are } 0.71 \text { for a } 10 \% \text { increase, } 0.1 \text { for } \\
\text { a } 30 \% \text { increase, } 0.07 \text { for a } 50 \% \text { increase, } 0.03 \text { for a } 70 \% \\
\text { increase and } 0.09 \text { for a } 90 \% \text { increase. }\end{array}$ \\
\hline & $\begin{array}{l}\text { Second, as a robustness check, the family structure of the } \\
\text { owners is taken into account. It is assumed that members } \\
\text { of the same family vote as a single block. }\end{array}$ \\
\hline Fam_10 & Equity is increased by $10 \%$. \\
\hline Fam_avg & $\begin{array}{l}\text { Different volumes of equity increases are considered with } \\
\text { the relative weights as in Ind_avg. }\end{array}$ \\
\hline
\end{tabular}


Table D: Descriptive Statistics

\begin{tabular}{|l|c|c|c|c|c|}
\hline Variable & Mean & Median & St. Dev. & Min & Max \\
\hline \hline Number of employees & 130 & 53 & 573 & 1 & 34,763 \\
Age (in years) & 27 & 21 & 20 & 1 & 145 \\
Total assets (in m. £) & 8.5 & 3.2 & 47.9 & 0.015 & 4,368 \\
Equity (Issued capital) (in m. £) & 0.246 & 0.025 & 1.52 & 0.000001 & 77.8 \\
Growth equity (in \%) & 0.30 & 0 & 7.89 & -35 & 150 \\
Avg. annual growth of & & & & & \\
total assets 1998-2001 (in \%) & 5.89 & 4.54 & 13.4 & -44.8 & 87.6 \\
Leverage (in \%) & 56.6 & 58.5 & 23.5 & 0 & 119.0 \\
Preference ratio (in \%) & 1.78 & 0 & 10.3 & 0 & 90.0 \\
Capital expenditure ratio (in \%) & 2.54 & 0.70 & 5.10 & -18.7 & 28.6 \\
ROA (in \%) & 6.31 & 5.08 & 9.07 & -25.2 & 49.6 \\
Number of owners & & & & & \\
Share largest owner (in \%) & 6.74 & 54.0 & 26.2 & 8.3 & 100 \\
Dummy largest owner manager & 0.75 & 1 & 0.43 & 0 & 1 \\
Potential loss of control, Ind_10 & 0.087 & 0 & 0.14 & 0 & 0.5 \\
Potential loss of control, Ind_avg & 0.11 & 0.054 & 0.13 & 0 & 0.5 \\
Potential loss of control, Fam_10 & 0.046 & 0 & 0.11 & 0 & 0.5 \\
Potential loss of control, Fam_avg & 0.066 & 0 & 0.11 & 0 & 0.5 \\
\hline
\end{tabular}

Note: Number of observations is $27,800-28,366$. 
Figure A: Distribution of the Number of Owners

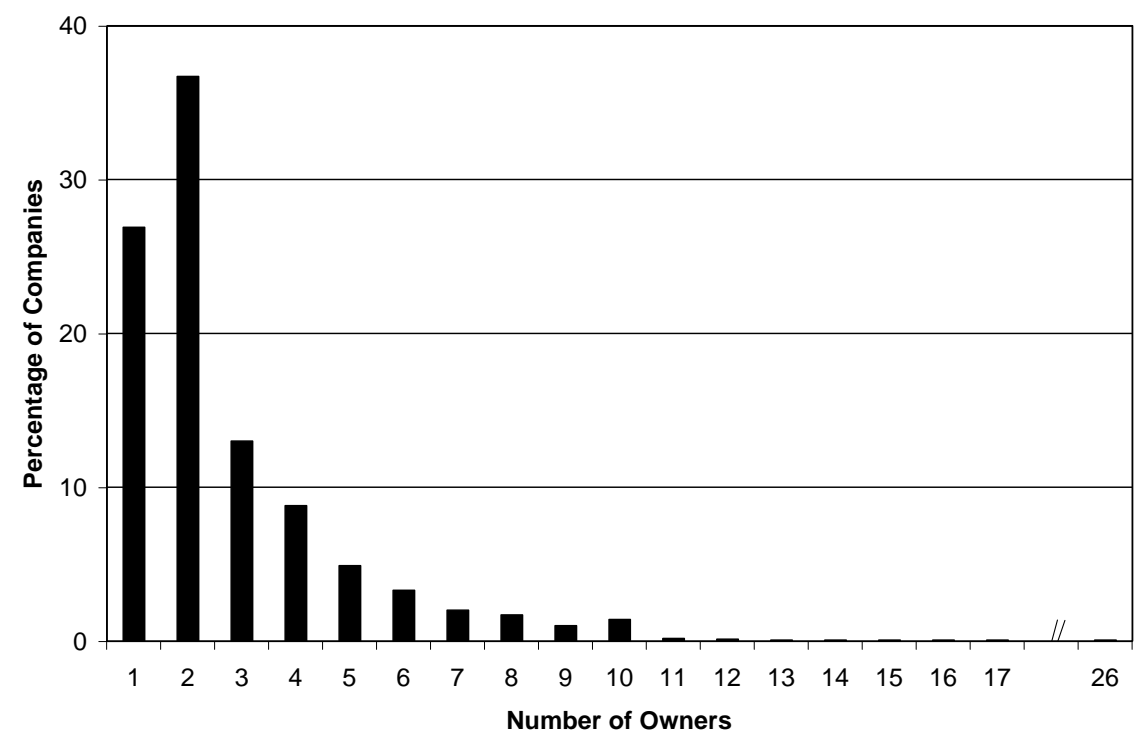

Figure B: Average Share Largest Owner by Age of Company

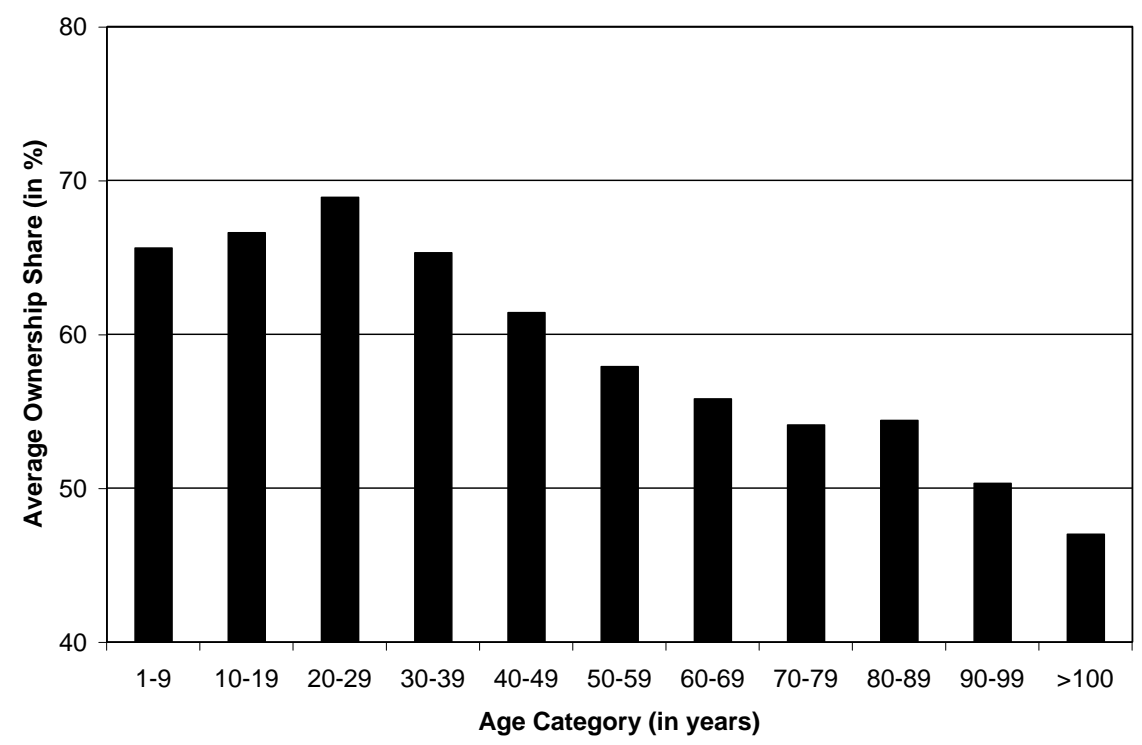


Figure C: Average Leverage by Age of Company

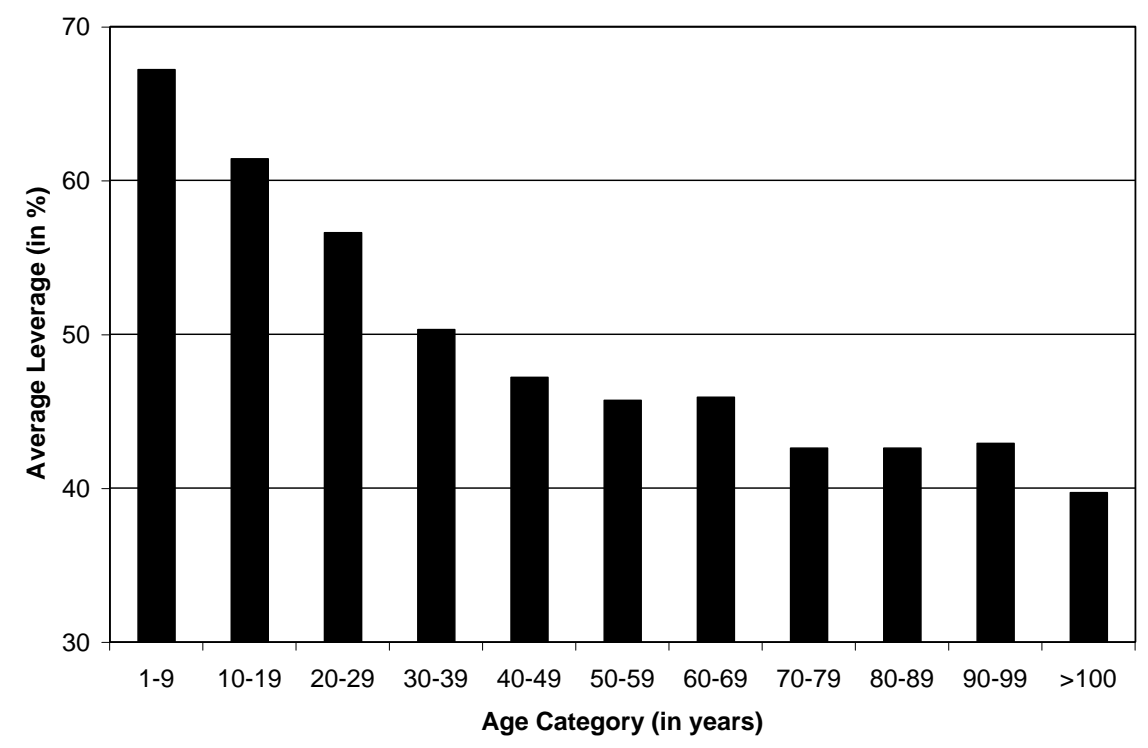

Figure D: Potential Loss of Control (Ind_10) According to Share Largest Owner

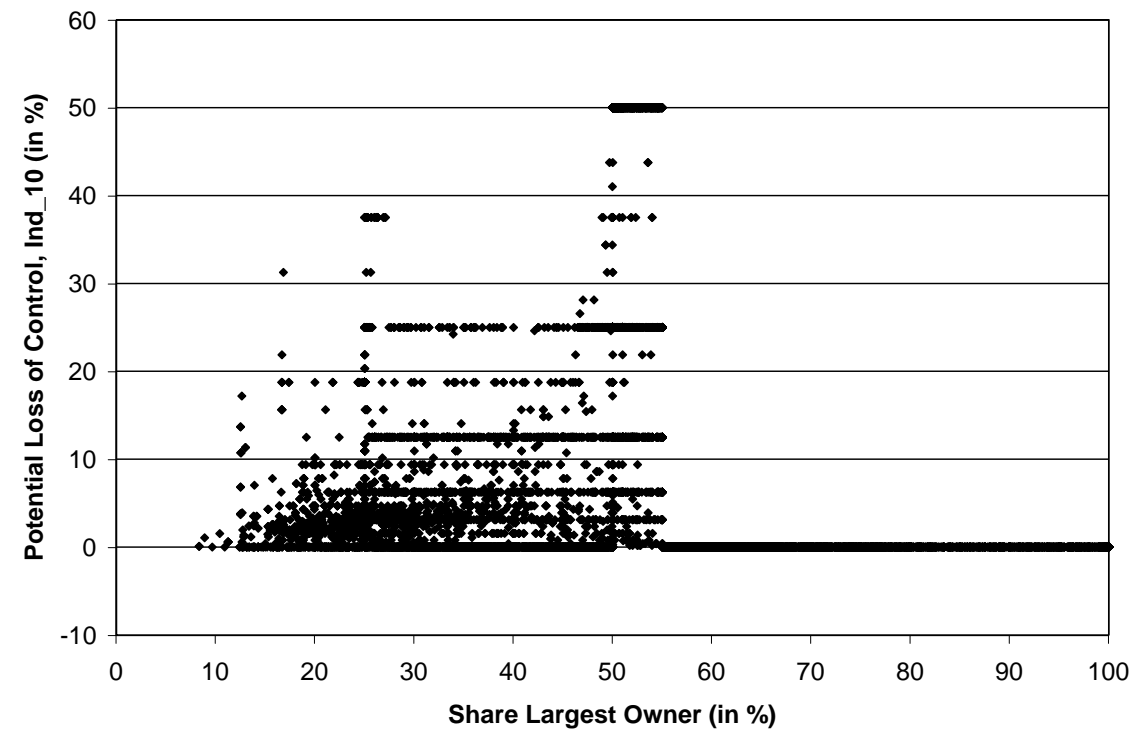


Figure E: Potential Loss of Control (Ind_avg) According to Share Largest Owner

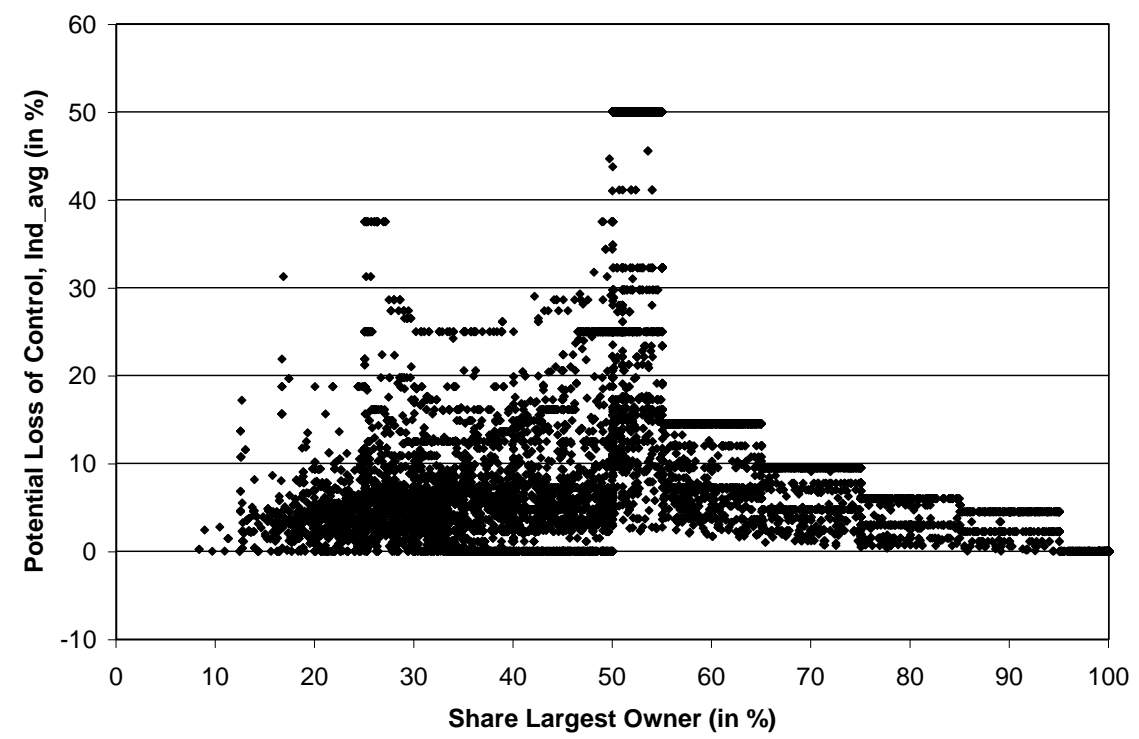




\section{References}

Aghion, P. and Bolton, P. (1992), 'An Incomplete Contracts Approach to Financial Contracting', Review of Economic Studies 59, 473-494.

Anderson, R. W. and Nyborg, K. G. (2001), 'Financing and Corporate Growth Under Repeated Moral Hazard', Financial Markets Group Discussion Paper 376, London.

Bank of England (2001), 'Finance for Small Firms - An Eight Report', London.

Barclay, M. J. and Holderness, C. G. (1989), 'Private Benefits from Control of Public Corporations', Journal of Financial Economics 25, 371-395.

Bebchuk, L. A. (1999), 'A Rent-Protection Theory of Corporate Ownership and Control', NBER Working Paper No. 7203.

Bennedsen, M. and Wolfenzon, D. (2000), 'The Balance of Power in Closely Held Corporations', Journal of Financial Economics 58, 113-139.

Burkart, M., Gromb, D. and Panunzi, F. (1998), 'Why Higher Takeover Premia Protect Minority Shareholders', Journal of Political Economy 106, 172-204.

Cressy, R. (1995), 'Business Borrowing and Control: A Theory of Entrepreneurial Types', Small Business Economics 7, 291-300.

Cressy, R. (2002), 'Introduction: Funding Gaps', Economic Journal 112, F1-F16.

Cressy, R. and Olofsson, C. (1997), 'The Financial Conditions for Swedish SMEs: Survey and Research Agenda', Small Business Economics 9, 179-194.

Cubbin, J. and Leech, D. (1983), 'The Effect of Shareholding Dispersion on the Degree of Control in British Companies: Theory and Measurement', Economic Journal 93, 351369.

de Meza, D. (2002), 'Overlending?', Economic Journal 112, F17-F31.

de Meza, D. and Webb, D. C. (1987), 'Too Much Investement: A Problem of Asymmetric Information', Quarterly Journal of Economics 102, 281-292. 
Dey, R., ed. (1994), British Companies Legistlation: Companies Act 1985, Insolvency Act 1986, Companies Act 1989 and Related Legislation, Croner CCH Group, Bicester.

Dyck, A. and Zingales, L. (2002), 'Private Benefits of Control: An International Comparison', NBER Working Paper No. 8711, forthcoming Journal of Finance.

Felsenthal, D. S. and Machover, M. (1998), The Measurement of Voting Power, Edward Elgar, Cheltenham.

Grossman, S. J. and Hart, O. D. (1988), 'One Share-One Vote and the Market for Corporate Control', Journal of Financial Economics 20, 175-202.

Harris, M. and Raviv, A. (1988), 'Corporate Governance: Voting Rights and Majority Rules', Journal of Financial Economics 20, 203-235.

Lang, L., Ofek, E. and Stulz, R. M. (1996), 'Leverage, Investment, and Firm Growth', Journal of Financial Economics 40, 3-29.

Lease, R. C., McConnell, J. J. and Mikkelson, W. H. (1983), 'The Market Value of Control in Publicly-Traded Corporations', Journal of Financial Economics 11, 439-471.

Leech, D. (2002), 'An Empirical Comparison of the Performance of Classical Power Indices', Political Studies 50, 1-22.

Leland, H. and Pyle, D. (1977), 'Information Asymmetries, Financial Structure and Financial Intermediaries', Journal of Finance 32, 371-387.

Moskowitz, T. J. and Vissing-Jørgensen, A. (2002), 'The Returns to Entrepreneurial Investment: A Private Equity Premium Puzzle?', American Economic Review 92, 745-778.

Myers, S. C. (1977), 'Determinants of Corporate Borrowing', Journal of Financial Economics 5, $147-175$.

Myers, S. C. and Majluf, N. S. (1984), 'Corporate Financing and Investment Decisions When Firms Have Information That Investors Do Not Have', Journal of Financial Economics 13, 187-221. 
NatWest/SBRT (2002), 'NatWest/SBRT Quarterly Survey of Small Business in Britain', Small Business Research Trust, March 2002.

Nickell, S., Nicolitsas, D. and Dryden, N. (1997), 'What Makes Firms Perform Well?', European Economic Review 41, 783-796.

Nicodano, G. and Sembenelli, A. (2000), 'Private Benefits, Block Transaction Premiums and Ownership Structure', mimeo.

Pagano, M., Panetta, F. and Zingales, L. (1998), 'Why Do Companies Go Public? An Empirical Analysis', Journal of Finance 53, 27-64.

Poutziouris, P., Chittenden, F. and Michaelas, N. (1998), 'The Financial Affairs of Private Companies', Tilney Fund Management, Liverpool.

Small Business Service (2003), 'Small and Medium Enterprise Statistics for the UK', London.

Wren, C. and Storey, D. J. (2002), 'Evaluating the Effect of Soft Business Support Upon Small Firm Performance', Oxford Economic Papers 54, 334-365.

Zingales, L. (1994), 'The Value of the Voting Right: A Study of the Milan Stock Exchange Experience', Review of Financial Studies 7, 125-148.

Zwiebel, J. (1995), 'Block Investment and Partial Benefits of Corporate Control', Review of Economic Studies 62, 161-185. 